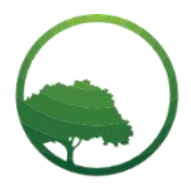

Research in Business \& Social Science

IJRBS VOL 10 NO 6 ISSN: 2147-4478

\title{
Vendor rights and violence: Challenges faced by female vendors in Zimbabwe
}

Courage Mlambo

(a) Mangosuthu University of Technology. Faculty of Public Administration and Economics

\author{
ARTICLE INFO \\ Article history: \\ Received 07 April 2021 \\ Received in rev. form 25 July 2021 \\ Accepted 22 Sept 2021 \\ Keywords: \\ Street Vending, Poverty, Police \\ Brutality, Women, Development \\ JEL Classification: \\ $\mathrm{O} 43$
}

\begin{abstract}
A B S T R A C T
The paper seeks to highlight the challenges faced by women street vendors in Zimbabwe. The paper provides an overview of the brutal attitudes displayed toward women and young girl vendors by law enforcement agencies in Zimbabwe. Street vending is an important source of income for the poor in the developing world. Street vending activities contribute to the livelihoods of millions of people and to national wellbeing at large, especially in developing countries. Secondary sources including journals, newspapers and online news articles were used in the compilation of this study. These sources were analysed for any insights into women street vendors' socio-economic status, police treatment of street vendors and working conditions. Street vendors experience arbitrary arrests, harassment, and confiscation of their wares and the government continues to move them out of the town and cities structures despite the unavailability of alternative accommodation. is a need for the government of Zimbabwe to see economic and social rights as a priority and the government should also protect women and girls from police brutality? Without the state's protection, women and young girls who ply their trade in the street will remain in a state of harassment, beatings and arbitrary arrest by the police.
\end{abstract}

(C) 2021 by the authors. Licensee SSBFNET, Istanbul, Turkey. This article is an open access article distributed under the terms and conditions of the Creative Commons Attribution (CC BY) license (http://creativecommons.org/licenses/by/4.0/).

\section{Introduction}

Street vendors are an integral part of urban economies around the world, offering easy access to a wide range of goods and services in public spaces (Reed, 2019). About 2.5 billion people, or half of the global labour force, work in the informal economy, the International Labour Organisation estimates (Recio, 2019). Street vending is the most visible form of this. Street vending is an important source of income for the poor in the developing world. Street vending activities contribute to the livelihoods of millions of people and to national wellbeing at large, especially in developing countries (Turner and Oswin, 2015; Uwitije, 2016). Low industrial growth, declining agricultural sector and limited expansion of formal sector employment in developing countries have increasingly forced the poor to take recourse to informal sources of livelihoods. Gamieldien, and van Niekerk (2017) concurs and states that although some hawkers are forced into the occupation by necessity or desperation, many acknowledge that it provides well for essential requirements, including shelter, food, education. Street vending is one such thriving source of self-employment across cities in the developing world. Abbot and Sotelo (2014) and Sharma and Pradhan (2017) notes that street traders operate is what is known as the 'invisible economy' and contribute largely to the national economy indirectly. Neary (2018) also provides a valuable service for the urban poor as it provides food and goods for a lower price. In several African countries, informal sector income accounts for over 40 percent of total urban income (Abbot and Sotelo, 2014).

However, despite its importance and contribution to the economy, street vending remains overlooked by state authorities. Sverdlik (2019) notes that street trading can create vital livelihoods, especially for women, but these providers are usually ignored and remain invisible. informal workers - and their livelihoods - tend to be ignored or excluded in city planning and local economic development. Gamieldien and Van Niekerk (2017) and Harvey (2019) further argues that informal workers are often misunderstood and undervalued, and negative stereotypes and myths about their work persist. This is further worsened by the actions of governments

* Corresponding author. ORCID ID:

(C) 2021 by the authors. Hosting by SSBFNET. Peer review under responsibility of Center for Strategic Studies in Business and Finance. https://doi.org/10.20525/ijrbs.v10i6.1197 
and municipal agencies. These institutions often prefer to evict street vendors from their places of work on the streets, to make the streets nice and empty, instead of looking at the issue of their livelihoods and how to regulate more effectively and inclusively. Racaud, Kago and Owuor (2018) and Texereira (2020) argue that law enforcement against street vending oscillates between tolerance and brutal eviction and street vendors of the global South therefore operate in a highly hostile and at times dangerous environment. Chen (2016) regard this forced removal of street vendors as exclusion of vendors from the economy and states that no amount of social and financial inclusion can compensate for the costs of having one's livelihood undermined or destroyed. Harvey (2019) further states that these forced removals and violence on street vendors can have an enormous negative impact on street vendors' earnings and the well-being of their families.

Racaud, Kago and Owuor (2018) state that despite street trade being a source of employment for a large number of city dwellers, its political legitimacy is weak and it therefore operates in conditions of uncertainty and hostility. The urban informal workforce, especially the working poor, need to be recognized, valued and supported as economic agents who contribute to the economy and to society. In cities across Africa, street traders are subject to ongoing "low-level harassment" informed by colonial approaches to urban governance (Gamieldien and Van Niekerk, 2017; Racaud, Kago and Owuor, 2018; Skinner cited in WIEDO, 2019). This ongoing harassment and intimidation of informal traders by the police and local government officials is frequently raised as a concern in the media and the public space (Xolo, 2018). Zimbabwe is not an exception to this; crackdowns on informal traders are a frequent occurrence in Zimbabwe (Roever and Skinner, 2016; Kulkarni, 2020; Mukeredzi, 2020). The fact that urban authorities harass and persecute street vendors should be a source of concern to policy makers and academics (Simango, 2017). Recognising that the economy of several developing economies, such as Zimbabwe, faces socio-economic problems there must be efforts by the government to ensure that traders in the informal sector are protected from police harassment and abuse. This forms the goal of this study.

The methodology of this study is largely based on desktop research. Secondary data from Zimbabwean human rights mechanisms, newspapers, and academic sources were used to gather information. Most of the information from these sources was not written with a view to research. Bryman (2012) argues that because they (secondary information/data) have not been created specifically for the purposes of research, possibility of a reactive effect can be largely discounted as a limitation on the validity of the data. However, de Vos (2011) is quick to point out that when studied and analysed for the purpose of research, data from secondary documents as a data collection method becomes operative.

This study did a comprehensive process of desktop research to gather, consolidate and draw conclusions from existing information that had been generated on vendor practises in Zimbabwe.

The paper aims to highlight the challenges faced by women street vendors in Zimbabwe. The paper provides an overview of the brutal attitudes displayed toward women and young girl vendors by law enforcement agencies in Zimbabwe

\section{Theoretical and Conceptual Background}

\section{Street Vending in Zimbabwe}

Street trading is a lifeline for hundreds of thousands in Zimbabwe (Simango, 2017; Moyo, 2019). This line of business has been there since Zimbabwe attained its independence ${ }^{1}$ and has "increased significantly since the year 2002 when the economy of Zimbabwe started to decline" (Ndoro-Mkombachoto, 2018). Severe economic and political crises have resulted in the informal economy overshadowing the formal economy. Njaya (2014), Nani (2020) and Mutsaka (2020) concurs and states that in Zimbabwe the informal sector has become the largest employer due to economic downturn and three quarters (76\%) of the economically active population earn their living in the informal sector (Zimbabwe National Statistics Agency, 2020). In 2018, the Zimbabwean Government acknowledged the growth of its informal economy, which the then Finance Minister Patrick Chinamasa described as the "new economy" in his budget presentation (The Herald, 2018). A study of informal economies that was published in January 2018 by the International Monetary Fund stated that Zimbabwe's informal economy is the third largest in the world at 60,6\% of Gross Domestic Product (IMF, 2018).

Some reports have estimated the unemployment rate in Zimbabwe to be as high as 95\% (Simango, 2017: Ratisai, 2018). A significant number of Zimbabweans have decided to engage in informal business as a way to earn a livelihood. As Zvorwadza quoted in Langa (2014) notes that vending is now an unavoidable reality as Zimbabweans cannot divorce themselves from the problem of unemployment. Harsh economic conditions coupled with increasing poverty and lack of formal employment opportunities have been the main driving forces for street vending (Human Rights Watch 2015: Ratisai, 2018 and Skinner and Balbuena, 2019). Most of these street vendors live in extreme poverty and they have no other source of income. One of the causes of the high poverty has been lack of creation of employment opportunities. It is estimated that indicate that 74 percent of households in Zimbabwe live in poverty (Quinn, 2017; UN, 2018; Louis, 2021; Chingono, 2021; UNICEF, 2021).

\footnotetext{
${ }^{I}$ Zimbabwe's informal sector emerged with the encroachment of colonial capitalism in the early twentieth century. During the colonial period, unemployed urban dwellers resorted to street vending, beer brewing, market gardening, prostitution, and other income-generating activities
} 
The Zimbabwean economy has over the past decade gone through structural shift that saw a number of formal businesses collapse. Statistics show that at least 10 firms close down every month (NSSA, 2013). As a result of this, livelihoods are now hinged on on income generating opportunities such as street vending. Vending is a reality in most urban local authorities and a direct response to the prevailing adverse socio-economic conditions (Gweru Residence Forum, 2019). A significant number of Zimbabweans have decided to engage in informal business as a way to earn a livelihood. Zvorwadza quoted in Langa (2014) argues that vending is now an unavoidable reality as Zimbabweans cannot divorce themselves from the problem of unemployment. Vendors are mushrooming everywhere in Zimbabwe and this indicates poverty (Gundani quoted in the Zimbabwe Independent, 2015). Zimbabwe's First Lady, Dr Grace Mugabe, further stated it is hard enough for street vendors to try and put food on the table for their families in a difficult economy, and the police was making their plight worse (Vikilahle, 2014 and Chinowaita, 2015).

Harsh social-economic circumstances have poverty are forcing more people into the streets to sell their wares. Street vending is found throughout Zimbabwe where vendors sell vegetables, fruits, cigarettes, air time, confectioneries, and many other commodities. This line of business consists of thousands of vendors selling wares meander for along the roads, pavements and street sidewalks and they serve a huge number of people in many cities and towns in Zimbabwe. Between 2007 and early 2009 the economy of Zimbabwe suffered severe economic turmoil. There was shortage of basic commodities in the shops and the retail sector neared total collapse. The street vending operations would become the source of basic commodities. It is in the streets that one could find bread, salt, sugar, cooking oil and many other basic commodities. It is for this reason that Matibenga quoted in Ncube (2014) states that women street vendors are feeding the nation. In Zimbabwe, street vending is seen as an important livelihood securing sector for the urban poor (Mangaga, 2007; Timalsina, 2007 and Ndiweni et al 2014).

Street vending is therefore an important source of employment and income for the urban poor in Zimbabwe. However, street vendors' fortunes have been hampered by law enforcement who chase, arrest them and take their wares. Despite street trade being a source of employment for a large number of city dwellers, its political legitimacy is weak and it therefore operates in conditions of uncertainty and hostility; street vendors are subject to constant harassment (Human Rights, Watch, 2015; Moyo, 2017; Dzirutwe, 2018; US Government, 2018). Street vendors experience arbitrary arrests, harassments and confiscation of the wares and government continues to move them out of the town and cities structures despite the unavailability of alternative accommodation.

The violence the Mugabe regime frequently meted out against vendors (and slum dwellers) has continued under President Mnangagwa's regime (Skinner and Balbuena, 2019). Although the police target both female and male vendors without any form of discrimination, women vendors are prone to police raids as they are not as quick as males in responding to police raids. Resultantly, women street vendors are vulnerable to arrests, sexual harrasment and confiscation of their stock ${ }^{2}$. According to Langa (2014) female vendors argue that they face more hardship than their male counterparts as some of them bring their babies with them to sell wares and some of them would be pregnant. Police harassment is not limited to goods confiscation or clearing illegally occupied space. Sexual favors may also be required, a problem specifically affecting female vendors (Cohen, Bhatt and Horn, 2000). Police officers demand sexual favours from women vendors they will have arrested in exchange for their freedom, a move which is illegal and a violation of their rights (Ncube, 2014). Paying bribes to public and private interests is so widespread and there is a local vocabulary for it. Hawkers in Zimbabwe call it "kudhiza or cut".

When the above information is taken into consideration, it can be realised that informal business, through street vending, is an important source of business ownership and income for many poor women and young girls in Zimbabwe. The country still faces economic problems and as a result job opportunities are still scarce. Recognising that the economy of Zimbabwe faces socioeconomic problems there must be efforts by the government to ensure that women and young girls in the informal sector are protected from police harassment and abuse. This forms the goal of this study.

\section{Women, Street Vending and Police Brutality}

Poverty, unemployment and restrictions on women to access and control of the means of production compel women to engage in informal businesses such as street vending. In Zimbabwe, many of the street vendors are women, and children (Moyo, 2018). Street vending is attractive to women because of its reasonably low start up and upkeep costs and it is also flexible in the sense that it allows women to juggle vending and family duties (Cohen and Bhatt and Horn, 2000 and Ruzvidzo, 2020). Vending near home can offer big advantages to women since they enjoy lower childcare and transport costs; they can better combine their livelihoods and household chores (Sverdlik, 2019). In other words street vending allow woman to do other household chores besides vending. Street vending has become an important source of income for many families in Zimbabwe. A Member of Parliament (MP) for Goromonzi West (a constituency in Zimbabwe), Ms Matibenga, argued that through vending, women street vendors are sending their children to school and supporting their families (Ncube, 2014). However, raids by the police threaten the viability of informal street vending which is a vital source if income for poor women and young girls. Such repressive actions have been carried to vicious extremes, when police, chase vendors from the city and even torture and in the process kill vendors. This was exemplified by the death of a female street vendor who collapsed whilst fleeing from the police in Masvingo. The vendor collapsed while running away from the

\footnotetext{
${ }^{2}$ It has been argued that police take these wares for their own use. "Nyamupinga, an MP, argued that there has never been an auction for these confiscated goods and no-one knew where these ware go and how they are disposed when they have been taken by the police? (Zanu PF MP for Goromonzi West, Beata Nyamupinga cited in Ncube, 2014). Another MP, Mr Gabbuza, the officials confiscate wares from vendors to eat with their families leaving desperate vendors with no source of income.
} 
chasing Zimbabwean Republic Police who wanted to confiscate her wares for allegedly vending without a licence. Instead of offering her help (giving first aid and taking her to a health facility) the police confiscated her wares and left her to be attended by other vendors and later died (New Zimbabwe, 2014).

In another extreme case in Masvingo, there was also havoc following an incident where a female vendor's baby was crashed by a council vehicle while her mother was running away from municipal police. Angry vendors and residents then assaulted a council driver, burnt a council vehicle and a commuter omnibus and chased a fire brigade team that intended to put out the fire (Langa, 2014). Masvingo Residents and Ratepayers Association (MURRA) blamed the city council for acting in a 'barbaric manner'. The repressive and dreaded actions of the municipal and state police also extend to sexual harassment. Moving a motion on the plight of women vendors at the hands of both state police and municipal authorities, MP Nyamupinga, accused the police of demanding to have sex police officers so that they can be released (Ncube, 2014). Female vendors claim municipal and state police touch their breasts and backside while searching for airtime vouchers which they would have hidden to avoid them being confiscated (Langa, 2014). These operations by the police are negatively impacting female vendors. Street vendors lose their stock, capital and income and dignity which then increase poverty and psychological problems.

\section{Government Response to Women Abuse and Street Vending}

The ever-increasing numbers of vendors on the streets is presenting a big problem for Zimbabwe's local government authorities. The local government authorities argue that it is illegal to sell in streets and in the central business districts. In 2015, Local Government Minister, Dr Chombo, pushed for the removal of vendors from the streets arguing they were compromising health standards. Dr Chombo argued that the upsurge of indiscriminate vending in urban areas had acutely affected the ambience of town and city environments while compromising the health of the residents" (Nhliziyo and Muvundisi, 2015). The Ministy of Local Government launched the "Sustainable clean-up campaign" in February 2015 in an attempt to restore order in Harare's city centre which had been invaded by vendors selling their wares on pavements. This was done amid the SADC summit ${ }^{3}$. The government is of the view that street vendors cause problems in the pavements. It is believed that street vending gives rise to disorderliness, overcrowding in city pavements, criminality and obstruction of ordinary citizens who would be walking on pavements. The National Vendors' Union of Zimbabwe (NVUZ), which represents vendors, ${ }^{4}$ also noted uncouth behaviour by some vendors who shout in the streets advertising their wares; harass ladies in miniskirts and litter in the streets, and some sell prohibited products like marijuana. However, the organization (NVUZ) was quick to point that it had the capacity to educate its members (street vendors) to stop littering and to engage in good behaviour to ensure the aesthetic value of the Central business district is maintained (Langa, 2014).

On the other hand, there are other state institutions that see no problem with street vendors' presence in the streets. For example, several National Parliament members are aware of the fact that police officers abuse their authority. A motion calling for stoppage of harassment of female vendors was moved in the National Assembly by MP Nyamupinga and Kuwadzana MP Ms Lucia Matibenga. MP Nyamupinga, introduced a motion on the ill-treatment of women in the informal trading sector by city authorities and municipality police (Muchemwa, 2014 and Ncube 2014). MP Nyamupinga claimed that police officers demand sexual favours from women vendors they will have arrested in exchange for their freedom. MP Nyamupinga acknowledged the role played by women in supporting their families through vending and blamed the government for using repressive laws to regulate street vending. Binga South MP, Mr Joel Gabbuza, supported this motion and described the habit of confiscating (by local authorities) street vendors wares as "satanic". The MP further revealed that the police officials confiscate the wares to eat with their families leaving desperate vendors with no source of income. However, in 2015, some members of Parliament urged the government to remove vendors who sold their wares at retail shops' entrances the MPs argued that these vendors should sell their wares in designated areas. However, registered vendors have been complaining about municipal council's inability to offer and improve vending terminals/facilities. This is despite the fact that they pay taxes daily and yet the council is not doing anything to improve their terminals. The council is not even providing toilets and running water to stop the spread of water bone diseases such as typhoid and cholera (National Vendors Union of Zimbabwe cited in NewZimbabwe, 2014).

In her "meet-the-people" tours, in 2014, former Zimbabwe's First Lady, Dr Grace Mugabe, ordered police to stop victimising struggling vendors. Dr Mugabe strongly condemned the actions of the police whom she ordered to stop harassing vendors. In March 2015 Dr Mugabe maintained that the police should not force them out from the streets - effectively setting herself on a collision path with the then Local Government minister Ignatius Chombo who had vowed to remove vendors off the streets in February 2015. Dr Mugabe urged government to ensure that a conducive environment is put in place for women's involvement in different sectors. Dr Mugabe urged the police to stop the practise of confisticating wares they would raided from desperate vendors.

One of the arguments raised by the Local Government authorities is that street vendors compromise environmental health standards and as a result they must be removed from the streets. It is a truism to say that good standards of environmental health are fundamental to the quality of life and well-being of citizens, and to healthy and sustainable economic development. Environmental health should, therefore, be integrated into all aspects of urban planning and management. In Zimbabwe street vendors have been associated with

\footnotetext{
${ }^{3}$ Aggressive policing is particularly notable just before major public and tourist events, on the assumption that orderly streets improve the image of the city to visitors

${ }^{4}$ It is the organisation that represents vendors
} 
health and safety risks and they have been seen to congest the pavements in the city centres. However, these claims by the government authorities have been dismissed by vendors who claim that the municipal councils are to blame for the environmental health problems. Harare suffered intermittent outbreaks of waterborne diseases due to dilapidated infrastructure epitomised by the devastating 2008 cholera outbreak that claimed 4000 lives (Ahmed, 2011; NewZimbabwe, 2015). Chimusoro et al (2018) and Amnesty International (2018) concur and state that since 2008, most of the cholera outbreaks in Zimbabwe were in urban settlements where the main drivers of cholera included the overloaded and dilapidated water and sanitation infrastructure which has been deteriorating over the years, inadequate water, contaminated water sources and poor water storage. The quality and quantity of water supplied, by the municipal councils in Zimbabwe, has dropped remarkably over the last decade. Key risk factors for cholera in Zimbabwe include the deterioration of sanitary and health infrastructure and increasing rural-urban migration which further strains the water and sanitation infrastructure (Mason, 2009: Amnesty International, 2018; MSF, 2018; Mafundikwa, 2018; WHO, 2018; Mukandavire, 2020).

The water and sewer systems of Zimbabwe's cities are on a state of collapse and as a result of this millions of Zimbabweans (including legal street vendor markets) lack access to safe and adequate supply of clean water. The World Bank Service Level Benchmarking 2013 revealed that the efficiency in collection of sewage is only 37 per cent, posing a serious health hazard as sewerage flows in open drains and storm drains (UNICEF, 2013). Several residential areas such as Chikurubi and Hatcliffe have no water supply at all. In some residents flowing raw sewage has been going on for half a decade leading to serious environmental and health hazards (Ahmed, 2011; Combined Harare Residents Assocation quoted in NewZimbabwe, 2015; Mafundikwa, 2018). This situation has resulted in the transmission of water-borne diseases such as cholera, dysentery and typhoid.

Street vendors have complained of poor service delivery by the municipal councils. For example, in Gweru, vendors demanded that council shuts down a transit dumping site at Kudzanayi bus terminus saying they feared an imminent health hazard (NewZimbabwe, 2015). This was after garbage had gone uncollected for days and had become a health and environment hazard. One vendor was quoted as saying that, because of the uncollected refuse, their customers had shun their place of vending because they feared an outbreak of diseases such as cholera. The Gweru council cited financial challenges as the reason they could not timeously provide the refuse collection services. The state of waste management, in Zimbabwe, remains erratic exacerbated by policy inconsistencies, failed road infrastructure and poor maintenance of trucks.

When the above information is taken into consideration, the council is to blame for any health and safety hazards in the urban and town areas. The council has been failing to offer basic services and this has disease outbreaks such as cholera and typhoid. It is poor management that generates problems of congestion and pollution (WIEDO, 2019). Furthermore, towards election time, street vendors are not harassed or evicted from their stalls. Political opportunism can also lead vendors to be targeted as easy scapegoats when highlevel officials feel pressed to show their power or need additional resources. A mayor of Mexico City exemplified this approach (Cohen, Bhatt and Horn, 2000). Previously vendors have been described by authorities as "a menace" in city centres, and were often blamed for "causing congestion" — but that all appears to have been forgotten as Zimbabwe inched closer to the 2018 polls (Chitagu, 2018). Roever and Skinner (2016) concur and argue that combined with political leaders' anger against the urban electorate who had largely voted for the opposition, was a fertile field for those who always desired urban "order" to gain ground. Many cities experience cycles in which local authorities tolerate, then regulate, and then evict street vendors in accordance with economic trends, election cycles and other urban management pressures (WIEDO, 2019).

\section{Discussion}

Street vending has been around for centuries all over the world. Gamieldien and Van Niekerk (2017) The informal economy (also known as the second economy) has been an important source of employment and the contribution of hawkers to job creation and economic growth, as 'street savvy' business people, has largely been overlooked. The informal sector of Africa's economy, often ignored by government statisticians, is vibrant and busy. This sector, however, has been undermined by policymakers who perceive street vending as a liability rather than a potential. some municipal by-laws and policies seem to treat the informal trade as a form of social security rather than facilitating it as a legitimate economic activity (Xolo, 2018). Hence street vendors are exposed to various challenges (Uwitije, 2016). Official planning documents do not include informal trading activities; they are "off the map". This invisibility largely stems from state rules that consider street vending illegal. Amid the harsh policies, street vendors devise ways to cope with poverty and their insecure livelihood (Recio, 2019).

The Supreme Court of India has noted that, from a consumer point of view, street vendors "considerably add to the comfort and convenience of the general public, by making available ordinary articles of everyday use for a comparatively lesser price". This is a particularly important role for the urban poor who cannot afford to shop at supermarkets (Roever and Skinner (2016). The urban informal workforce, especially the working poor, need to be recognized, valued and supported as economic agents who contribute to the economy and to society (Chen, 2016). By supporting street vendors, cities can foster equitable development and improve the livelihood of society's most vulnerable populations. By nourishing these workers' livelihoods, policymakers can finally recognise the pivotal role of street foods for the urban poor. With greater policy support and inclusive organisations like the FVA, vendors can lead the way towards healthy food and more equitable development in informal settlements (Sverdlik, 2019). 
Street vending necessitated by increased poverty and the rising unemployment levels in the country rendering the informal sector both a livelihood and income generating venture among the urban poor. Despite the hard work and innovative methods being displayed by vendors plying the streets, no support has come from the government to encourage growth in the informal sector or to create conducive working environments (Zvorwadza cited Moyo, 2018). The main question that needs to be answered is: Where else can the vendors earn a living if they don't descend on the streets?" Given the current economic situation is Zimbabwe, informal trading is the only viable option that people can pursue. The government should either support or formalise the informal sector and strategically place it for sustainable, macroeconomic transformation. Currently there is limited dialogue and engagement between the state mechanism (council, Ministry of local government and the vending public). The government needs to adopt a human right based approach to solve the problems that street vendors are facing. The human rights based approach is a theoretical framework for the advancement of human development that is based on international human rights principles and directed to protecting human rights (UNICEF, 2015). From a street vendors' view, this approach notes that women street vendors have very limited rights and regulatory framework is not responsive to their socio-economic conditions (unemployment and poverty). The human rights based approach seeks to analyse inequalities which lie at the heart of development problems and redress discriminatory practices and unjust distributions of power that impede development progress (UNICEF, 2015).

Flowing from this human rights approach is the need for the Zimbabwean government to allow street vendors to participate fully in the making, review and adoption of street vending laws and policies. Participatory processes that involve stakeholders in the design as well as the ongoing governance of public space management have the potential to create buy-in, trust, and accountability, and ultimately result in more sustainable and mutually beneficial outcomes (Harvey, 2019). Participation is an important concept of administrative law and it requires the involvement of those whose livelihoods will be affected by a particular government decision or policy to actively and freely participate in its making and adoption of that decision or policy. The participation of Zimbabwean women in politics and decision making is a fundamental pre-requisite for gender equality and women empowerment (Chinoiwaita, 2015). A human rights based approach requires a meaningful and active involvement of people in activities, processes and decisions that have an adverse effect on the lives. In this regard, the Zimbabwean government should grant street vendor access to street trading information, stop harassing and abusing them and then include these vendors in the street vending decision making process. All these are absent in Zimbabwe; vendors are looked down upon and the government uses municipal and state police to harass, chase, torture and in extreme case, abusing women vendors. From human rights based approach harassing, torturing and sexually abusing them is a violation of street vendors' rights. These restrictive street trading laws and coercive government actions against street traders, by the Zimbabwean local government authorities, should, thus, be eliminated and stopped respectively.

The study concludes that women bore the brunt of poverty and as such there is an urgent need to come up with interventions that will cushion women from sexual abuse, torture, harassment and corruption as they engage in street vending activities. Women street vendors need to get the recognition of their economic contribution and potential as well as the removal of long-standing policy biases against them.

\section{Conclusion}

The harsh economic and socio-economic conditions in Zimbabwe require that restrictive street trading laws and coercive government actions against street traders be eliminated and stopped respectively. There is need for the government of Zimbabwe to see economic and social rights as a priority and the government should also protect women and girls from police brutality. Without the state's protection women and young girls who ply their trade in the street will remain in a state of harassment, beating and arbitrary arrest by the police. The government must recognize that all policies and measures adopted to advance sustainable development must be firmly grounded in, and respectful of, all internationally agreed human rights and fundamental freedoms, including the right to development. Particular care must be taken to prevent and remedy any negative impacts on the human rights of vulnerable and marginalized groups, including, persons living in poverty, women and children. The empowerment of women, the protection of their rights, and their meaningful participation in decision making must be assured.

A human rights approach requires active and informed participation by the women in the formulation, implementation, and monitoring of regulations and laws on street trading. Participation as an important concept of good governance means involving those whose livelihoods will be affected by a particular decision to participate in its planning and monitoring the implementation of that decision. In this regard, the Zimbabwean government should grant street vendor access to street trading information, stop harassing and abusing them and then include these vendors in the street vending decision making process. All these are absent in Zimbabwe; vendors are looked down upon and the government uses municipal and state police to harass, chase, torture and in extreme case, abusing women vendors. From human rights based approach harassing, torturing and sexually abusing them is a violation of street vendors' rights. These restrictive street trading laws and coercive government actions against street traders, by the Zimbabwean local government authorities, should, thus, be eliminated and stopped respectively.

\section{References}

Abbot, T and Sotelo, L.S. (2014). Recognizing the role of gender in the informal urban economy. https://thecityfix.com/blog/gender-informal-economy-vendors-inclusive-women-thomas-abbot-lizzette-sotelo All Africa. (2014). Zimbabwe: Vendors Seek MP Help Over Police Harassment. http://allafrica.com/stories/201406070021.html 
Amhed., T. Bardhan, P.K., Iqbal, A., Mazumder, R.n., Khan, A.S. (2011). The 2008 Cholera Epidemic in Zimbabwe: Experience of the icddr,b Team in the Field.

https://www.ncbi.nlm.nih.gov/pmc/articles/PMC3225117/\#: :text=The\%20poor\%20communication\%20and\%20transporta tion,of\%20cholera\%20throughout $\% 20$ the $\% 20$ country.

Amnesty International. (2018). Zimbabwe: Cholera outbreak highlights failure to invest in infrastructure and health system. https://www.amnesty.org/en/latest/news/2018/09/zimbabwe-cholera-outbreak-highlights-failure-to-invest-in-infrastructureand-health-system/

Bryman, A. (2012). Social Research methods (4e). New York, Oxford University Press

Chaeruka, D. (2013). Mutare vendors up in arms. http://www.theworkerzimbabwe.com/worker/FEBRUARY2012.pdf

Chen, M. (2016). Inclusive cities for informal workers. https://blogs.worldbank.org/jobs/inclusive-cities-informal-workers

Chimusoro, A., Maphosa, S., Manangazira, P., Phiri, I., Nhende, T. (2018). Responding to Cholera Outbreaks in Zimbabwe: Building Resilience over Time. https://www.intechopen.com/books/current-issues-in-global-health/responding-to-choleraoutbreaks-in-zimbabwe-building-resilience-over-time

Chingono, N. (2020). Half of Zimbabweans fell into extreme poverty during Covid. https://www.theguardian.com/globaldevelopment/2021/jun/21/half-of-zimbabweans-fell-into-extreme-poverty-during-covid

Chinowait, M. (2015). Grace, Chombo on collision path. http://www.dailynews.co.zw/articles/2015/03/07/grace-chombo-oncollision-path

Chitagu, T. (2018). Street vendors could make or break Zimbabwe's presidential hopefuls https://www.timeslive.co.za/politics/2018-07-27-street-vendors-could-make-or-break-zimbabwes-presidential-hopefuls/

Cohen, M., Bhatt, M and Horn, P. (2000). Women Street Vendors: The Road to Recognition. https://knowledgecommons.popcouncil.org/cgi/viewcontent.cgi?article=1187\&context=departments_sbsr-pgy

De vos, A.S, Strydom, H, Fouche, C.B and Delport, C.S.L. (2011). Research at Grassroots; For The Social Sciences and Human Service Professions. Pretoria, Van Schaik Publishers

Gamieldien, F and van Niekerk, L. (2017). Street vending in South Africa: An entrepreneurial occupation

Gamieldien, F., and van Niekerk. L. (2017). Street vending in South Africa: An entrepreneurial occupation. http://www.scielo.org.za/scielo.php?script=sci_arttext\&pid=S2310-38332017000100005

Gweru Residence Forum. (2019). Gweru City Council Vendor Persecution Blitz Must Stop. http://kubatana.net/2019/01/30/gwerucity-council-vendor persecution-blitz-must-stop/

Harvey, J. (2019). Wiego: How Cities Can Achieve Public Space For All. http://www.worldurbancampaign.org/wiego-how-citiescan-achieve-public-space-all

Human rights Watch. (2015). Zimbabwe: Violent Crackdown on Street Vendors Drop Charges; Free Detained Sellers, Activists. https://www.hrw.org/news/2015/07/29/zimbabwe-violent-crackdown-street-vendors

IMF. (2018). Shadow Economies Around the World: What Did We Learn Over the Last 20 Years? International Monetary Fund

Kimberlin, C.L and Winterstein, A.G. (2008). Validity and reliability of measurement instruments used in research. www.ncbi.nlm.nih.gov/pubmed/19020196

Kulkarni, P. (2020). Small vendors hard hit by government ordered demolitions in Zimbabwe. Peoples Dispatch. 29 April.

Kura, S.Y.B . (2012). Qualitative and Quantitative Approaches to the Study of Poverty: Taming the Tensions and Appreciating the Complementarities. www.nova.edu/ssss/QR/QR17/kura.pdf

Langa, V. (2014). Vendors recount hell at hands of council police. https://www.newsday.co.zw/2014/08/09/vendors-recount-hellhands-council-police/

Loius, P. (2020). What To Know About Poverty In Zimbabwe. https://borgenproject.org/tag/poverty-in-zimbabwe/

Mafundikwa, I. (2018). FACTSHEET: Cholera in Zimbabwe. https://zimfact.org/factsheet-cholera-in-zimbabwe/

Moyo, J. (2014). Moyo attacks ZRP: Full statement. http://www.newzimbabwe.com/news-15558Moyo+attacks+ZRP+Full+statement/news.aspx

Moyo, J. (2017). FEATURE-Zimbabwe's street vendors use card payments, cars to stay ahead. http://news.trust.org/item/20170214120535-1ap1g/

MSF. (2018). Zimbabwe: Responding to cholera in Harare. https://www.msf.org.za/news-and-resources/latest-news/zimbabweresponding-cholera-harare

Muchemwa, S. (2014). Kill Parks rangers, says MP. http://www.chronicle.co.zw/kill-parks-rangers-says-mp/

Mukandavire, Z., Manangazira, P., Nyabadza, F., Cuadros, D., Musuka, G. (2020). Stemming cholera tides in Zimbabwe through mass vaccination

Mukeredzi, T. (2020). Dying of hunger': Zimbabwe street vendors hit by coronavirus clampdown. https://news.trust.org/item/20200616041603-v7z5f

Mutsaka, F. (2020). Many Zimbabweans sell goods from their cars in hard times. https://apnews.com/article/574861599e5a2443f572c8b49c8f27de

Nani, V. (2020). Trading Space Rivalry between Street Vendors and Shop-Based Traders in Bulawayo Metropolitan Province, Zimbabwe: A Conceptual Perspective for Co-Existence. file://C:/Users/Admin/Downloads/12145-Article\%20Text-441161-10-20200715.pdf

Ncube, X. (2014). No sex, no freedom. www.thezimmail.co.zw/2014/07/16/no-sex-no-freedom/ 
Ndoro-Mkombachoto, G. (2018). Time vending was included into identifiable economy. https://www.thestandard.co.zw/2018/01/28/time-vending-included-identifiable-economy/

Neary, J. (2018). Street vendors of Manila. http://sueuaa.org/blog/street-vendors-manila

NewZimbabwe. (2014). Cops blamed for Masvingo Vendors' death. http://www.newzimbabwe.com/news-14931 Masvingo+cops+blamed+for+vendor\%E2\%80\%99s+death/news.aspx

Newzimbabwe. (2015. Burst pipes, raw sewage hre's image; chra. http://allafrica.com/stories/201503070151.html

Nhliziyo, D and Muvundusi, J. (2015). Chombo wants vendors off the streets. http://www.dailynews.co.zw/articles/2015/02/01/chombo-wants-vendors-off-the-streets

Ohio State University. (2020). Why use newspapers. https://guides.osu.edu/newspapers/why_use

Quinn, A.L. (2017). Causes Of Poverty In Zimbabwe. https://borgenproject.org/causes-of-poverty-in-zimbabwe/

Racaud, S., Kago, J., and Owuor, S. (2018). Introduction: Contested Street: Informal Street Vending and its Contradictions. https://journals.openedition.org/articulo/3719

Ratisai, C. (2018). Road to inclusivity for street vendors. https://www.theindependent.co.zw/2018/03/24/road-inclusivity-streetvendors/

Recio, R.B. (2019). Street vendors' self-help strategies highlight cities' neglect of how the other half survive. https://theconversation.com/street-vendors-self-help-strategies-highlight-cities neglect-of-how-the-other-half-survive110283

Reed, S.O. (2019). Vital Contributors to Urban Economies. https://www.wiego.org/informal-economy/occupational-groups/streetvendors

Roever, S, and Skinner, C. (2016). Street vendors and cities. https://journals.sagepub.com/doi/full/10).1177/0956247816653898

Ruzvido. R. (2020). Gender should be central to Africa's COVID-19 economic recovery initiatives. https://www.uneca.org/archive/stories/gender-should-be-central-africa\%E2\%80\%99s-covid-19-economic-recoveryinitiatives

Sharma, P and Pradhan, P.K. (2017). The Petty Street Vendors and Their Livelihoods of the Kathmandu Valley Cities, Nepal

Shenton, A.K. (2004). Strategies for ensuring trustworthiness in qualitative research projects. www.crec.co.uk/docs/Trustworthypaper.pdf

Sibanda, T. (2011). Zimbabwe: Police Beat Up Commuters and Vendors in Bulawayo. http://allafrica.com/stories/201112070315.html

Simango, L. (2017). Illegal Street Vending On Bulawayo Central Business District Urban Space: Challenges And Possible Solutions . http://ir.msu.ac.zw:8080/xmlui/bitstream/handle/11408/2955/R145193H.pdf?sequence=1\&isAllowed=y

Skinner, C and Balbuena, P. (2019). Where are the inclusive cities? Street vendors globally face increasing hostility. https://www.wiego.org/blog/where-are-inclusive cities-street-vendors-globally-face-increasing-hostility

Sverdlik, S. (2019. Nourishing livelihoods: the food vendors sustaining Nairobi's slums

Teixereira, M. (2020). Informal traders are not criminals: stop police violence in Zimbabwe! http://streetnet.org.za/2020/07/29/informal-traders-are-not-criminals-stop-police-violence-in-zimbabwe/

The Herald. (2018). Zim has world's second largest informal economy: IMF. https://www.herald.co.zw/zim-has-worlds-secondlargest-informal-economy-imf/

Turner, S and Oswin, N. (2015). Itinerant livelihoods: Street vending-scapes and the politics of mobility in upland socialist Vietnam

UN. (2018). Eradicate extreme poverty and hunger. http://www.zw.one.un.org/togetherwedeliver/millennium-developmentgoals/1-eradicate-extreme-poverty-and-hunger

UNICEF, 2021. Half of Zimbabweans faced extreme poverty in 2020 due to COVID-19: Rapid Poverty Income Consumption and Expenditure Survey (PICES). https://www.unicef.org/zimbabwe/press-releases/half-zimbabweans-faced-extreme-poverty2020-due-covid-19-rapid-poverty-income

UNICEF. (2013). UNICEF Annual Report 2013 - Zimbabwe. www.unicef.org/about/annualreport/files/Zimbabwe_COAR_2013.pdf

UNICEF. (2015). Human rights based approach to programming. http://www.unicef.org/policyanalysis/rights/

Uwitije, C. (2016). Contributions of Street Vending on Livelihood of Urban Low Income Households in the City of Kigali, Rwanda. http://erepository.uonbi.ac.ke/handle/11295/97752

Vikilahle, L. (2014). Grace Mugabe takes a swipe at police for allegedly harrasing vendors. http://zimbabwe.news24).com/National-News/Grace-Mugabe-takes-a-swipe-at-police-for-allegedly-harrasing-vendors20141007

Wesley, J.J. (2010). Qualitative Document Analysis in Political Science. https://www.poltext.org/sites/poltext.../p2wesley._09102010_131253.pdf

WHO. (2018). Cholera - Zimbabwe. Disease outbreak news: Update. https://www.who.int/csr/don/05-october-2018-cholerazimbabwe/en/

WIEDO. (2019. Key Debates about Street Vending. https://www.wiego.org/key-debates about-street-vending

Williams, F.P and McShane, M.D. (2010). Criminological theory. $5^{\text {th }}$ Ed. New Jersey, Prentice Halls 
Xolo, N. (2018). Durban street vendors "overlooked and undermined" by government.

https://www.news24).com/SouthAfrica/News/overlooked-and-undermined-the-challenges-durban-street-vendors-face20180725

Zimbabwe National Statistics Agency (2020). 2019 labour force and child labour survey report

Publisher's Note: SSBFNET stays neutral with regard to jurisdictional claims in published maps and institutional affiliations.

\section{(c) (1)}

() 2021 by the authors. Licensee SSBFNET, Istanbul, Turkey. This article is an open access article distributed under the terms and conditions of the Creative Commons Attribution (CC BY) license (http://creativecommons.org/licenses/by/4.0/).

International Journal of Research in Business and Social Science (2147-4478) by SSBFNET is licensed under a Creative Commons Attribution 4.0 International License. 